\title{
Evaluation of the effectiveness of innovative activities of companies in the agro-industrial complex in the context of the investment process
}

\author{
Yulia Verchenko ${ }^{1, *}$, Maria Glyzina ${ }^{1}$, Aida Takmazyan ${ }^{2}$, and Karina Samoylova ${ }^{2}$ \\ ${ }^{1}$ Don State Technical University, Gagarin Square, 1, 344003 Rostov-on-Don, Russia \\ ${ }^{2}$ Rostov State Economic University, B. Sadovaya str., 69, 344002 Rostov-on-Don, Russia
}

\begin{abstract}
The study presents the results of studying the relationship between the effectiveness of innovation and the investment process, based on a comparison of concepts, analysis of the return on investment by type of activity, and ranking of factors of the effectiveness of innovation. The article presents a comparative analysis of methods for determining the effectiveness of innovative activities, which showed the quantitative ratio of factors that limit innovation and typical assessment methods. The key principle of building a system for the effectiveness of innovative activities of companies in the agro-industrial complex in the context of the investment process has been determined. An experimental test of the methodology for assessing the effectiveness of innovative activities from the investment position was carried out and a complex for the development of innovative activities was developed, which determined the opportunity to identify the most promising market niches of the company.
\end{abstract}

\section{Introduction}

Speaking about the effectiveness of innovative activities of companies in the agro-industrial complex, first of all, they determine its effectiveness, which is not necessarily related to the financial aspect. Among other things, the effectiveness of innovation can be viewed from the consumer's side, when not only the cost savings associated with the consumption of innovative products come to the fore, but also other intangible effects aimed at more complete satisfaction of needs [1].

Due to the fact that in the literature and practice, innovation is supplemented, and often replaced by investment, explaining that innovation is not possible without investment, the study conducted a comparative analysis of these two types of activities in terms of performance (table 1) [2].

\footnotetext{
*Corresponding author: u_verchenko@mail.ru
} 
Table 1. Comparison of the concepts of investment and innovation

\begin{tabular}{|c|c|c|}
\hline Comparison criteria & Innovation activities & Investment activities \\
\hline Effectiveness & $\begin{array}{l}\text { Patent clearance, number of advanced } \\
\text { technologies created, volumes of advanced } \\
\text { technologies trade }\end{array}$ & $\begin{array}{l}\text { Financial result, payback } \\
\text { period. }\end{array}$ \\
\hline Efficiency & $\begin{array}{l}\text { Bilateral interest from both the innovation } \\
\text { organization and the innovation technology } \\
\text { consumer }\end{array}$ & $\begin{array}{l}\text { Interested in the investor } \\
\text { himself. }\end{array}$ \\
\hline $\begin{array}{l}\text { Approaches to } \\
\text { calculating } \\
\text { efficiency }\end{array}$ & \multicolumn{2}{|l|}{ Based on the principle of discounting } \\
\hline Parties concerned & Innovation organizations, $R \& D$ & Investors \\
\hline
\end{tabular}

If we carry out a comparative analysis of the profitability of invested funds by type of activity, we will get the following results [3] (Figure 1).

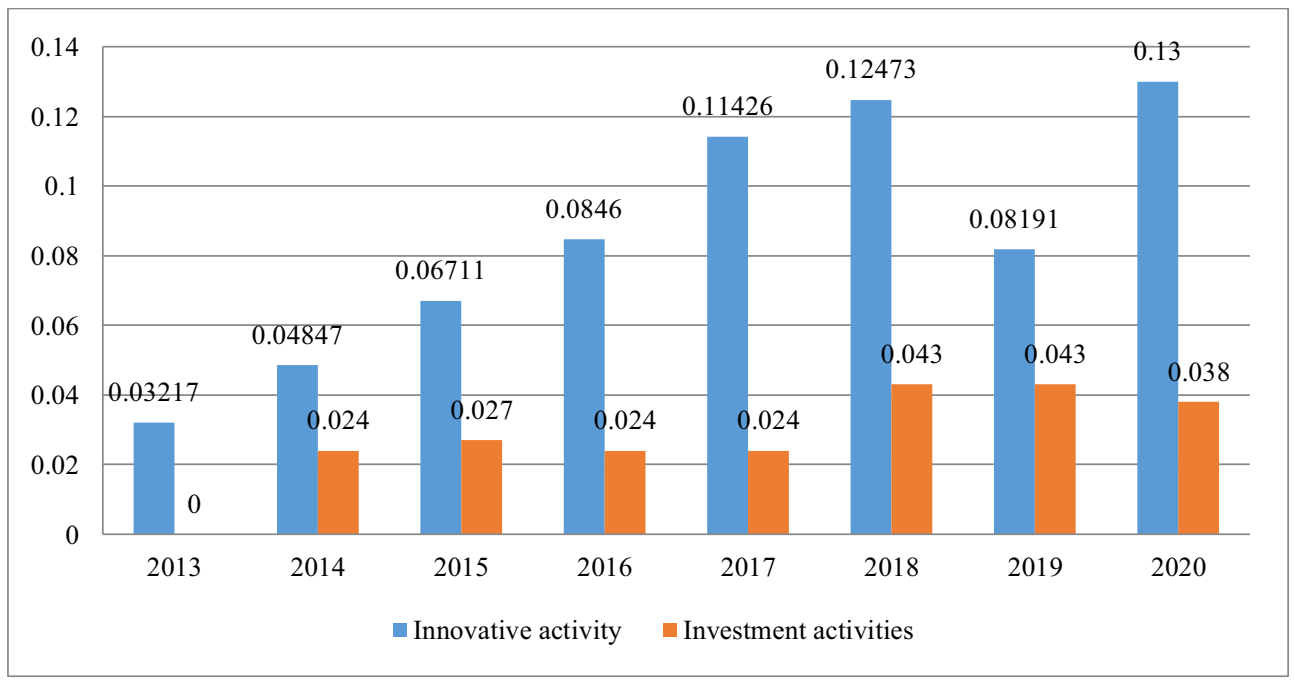

Fig.1. Income per ruble of invested funds in innovation and investment activities

It can be seen from the figure that the greatest efficiency from an economic point of view for an investor, of great interest will be occupied by investment (financial or natural) activities, which is determined by higher incomes in comparison with innovation. Innovation activity during the analyzed years demonstrates a fairly stable dynamics. However, the economic effect in the general case does not reflect the efficiency that can be obtained from innovation [4].

Despite the various widespread methodological recommendations in domestic and foreign literature, the effectiveness of innovative activity should be expressed not only by the income from investment of funds, but also by the result that is also obtained from the consumer [5]. 


\section{Materials and methods}

The problem of forming a methodology for determining the effectiveness of innovation is associated with a number of difficulties, the main of which, in our opinion, are [6]:

1) Lack of any generally accepted assessment guidelines.

2) Uncertainty in the structure of the effectiveness of innovation.

3) Closedness of information on which any external economic assessment can be based for a third-party investor.

In statistical observation, there are three groups of factors that, in the opinion of innovatively active organizations, impede innovative activities, and, therefore, affect the assessment of their effectiveness [7].

Having ranked the obstacle factors according to the strength of the impact, we obtained the following result (table 2).

Table 2. Ranking of factors of efficiency of innovation activity

\begin{tabular}{|c|c|c|c|c|c|}
\hline \multirow{2}{*}{ Factors } & \multicolumn{5}{|c|}{ The degree of influence } \\
\hline & 1 & 2 & 3 & 4 & 5 \\
\hline \multicolumn{6}{|c|}{ Economic forces } \\
\hline Lack of own funds & & & & & $23,7 \%$ \\
\hline Lack of financial support from the state & & & & $11,5 \%$ & \\
\hline Low demand for goods, works, services & & $4,3 \%$ & & & \\
\hline High cost of innovation & & & & & $15,6 \%$ \\
\hline High economic risk & & & & $8,7 \%$ & \\
\hline \multicolumn{6}{|c|}{ Internal factors } \\
\hline Low innovation potential of the organization & & & & $9,8 \%$ & \\
\hline Lack of qualified personnel & & & $5,4 \%$ & & \\
\hline Lack of information about new technologies & & & $5,1 \%$ & & \\
\hline Lack of information about sales markets & $2,7 \%$ & & & & \\
\hline Underdevelopment of cooperative ties. & $2,4 \%$ & & & & \\
\hline \multicolumn{6}{|c|}{ Other factors } \\
\hline $\begin{array}{l}\text { Lack of legislative and regulatory documents } \\
\text { that regulate and stimulate innovation }\end{array}$ & & $4,4 \%$ & & & \\
\hline $\begin{array}{l}\text { Underdevelopment of innovation infrastructure } \\
\text { (intermediary, information, legal, banking, } \\
\text { other services) }\end{array}$ & $3,1 \%$ & & & & \\
\hline $\begin{array}{l}\text { Uncertainty of the economic benefits of using } \\
\text { intellectual property }\end{array}$ & & & $4,4 \%$ & & \\
\hline
\end{tabular}

The uncertainty of the economic benefits from the use of intellectual property, according to the respondents, has an average power of influence, but, nevertheless, does not lose its relevance [8]. 
Based on the presented results of determining the effectiveness of innovation activities based on the data of the Federal Statistics Service, as well as on the analysis of the results of efficiency coefficients, we will try to identify factors that allow us to determine the effectiveness of innovation activities with a view to its subsequent investment [9].

The analysis was carried out on the basis of data provided by the company of the agroindustrial complex, while paying attention to the target orientation of each of the methods (Table 3).

Table 3. Comparative analysis of methods for determining the effectiveness of innovation

\begin{tabular}{|c|c|c|c|c|c|c|}
\hline & $\begin{array}{l}\text { Economic } \\
\text { forces }\end{array}$ & $\begin{array}{l}\text { Internal } \\
\text { factors }\end{array}$ & $\begin{array}{c}\text { Political } \\
\text { and legal } \\
\text { factors }\end{array}$ & $\begin{array}{l}\text { Infrastructu } \\
\text { re factors }\end{array}$ & $\begin{array}{c}\text { Invest } \\
\text { ment } \\
\text { factors }\end{array}$ & $\begin{array}{l}\text { Other } \\
\text { factors }\end{array}$ \\
\hline NPV & & & & & & \\
\hline IRR & & & & & & \\
\hline PI & & & & & & \\
\hline $\mathrm{CBA}$ & & & & & & \\
\hline $\begin{array}{l}\text { Innovation } \\
\text { coefficient }\end{array}$ & & & & & & \\
\hline $\begin{array}{l}\text { Vector } \\
\text { forecasting } \\
\text { method }\end{array}$ & & & & & & \\
\hline ROI & & & & & & \\
\hline $\begin{array}{l}\text { State Gate } \\
\text { model }\end{array}$ & & & & & & \\
\hline Kano method & & & & & & \\
\hline Real options & & & & & & \\
\hline
\end{tabular}

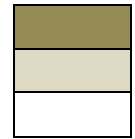

- allows you to take into account the factor;

- the factor is taken into account partially or indirectly; - connection could not be established.

If we pay attention to the quantitative ratio of factors that limit innovation and evaluation methods, we get the following ratio [10]:

1) $80 \%$ of assessment methods are aimed at $39.3 \%$ of economic factors - constraints;

2) $40 \%$ of assessment methods are aimed at $24.6 \%$ of internal factors - constraints;

3) $5 \%$ of assessment methods are aimed at $4.4 \%$ of political and legal factors - constraints

4) $20 \%$ of assessment methods are aimed at $3.1 \%$ of infrastructure factors constraintsнренр;

5) $70 \%$ of assessment methods are aimed at $24.3 \%$ of investment factors - constraints;

6) $25 \%$ of assessment methods are aimed at $4.4 \%$ of other limiting factors.

Based on the results of the analysis, we can conclude that a more acceptable assessment of the effectiveness of innovation will be a full combination of factors - constraints, assessment methods, assessment indicators [11]. In turn, the entire system for determining efficiency should be built according to the following principle: 
1. The degree of influence of the factors of the first and second factors that they are capable of exerting on the overall efficiency of innovation.

2. Behavior of factors of the third class under the change of the first two.

3. General structure of the assessment for all three classes of factors.

4. Scheme for assessing the effectiveness of innovation in the context of the investment process.

\section{Results}

After analyzing the results from the implementation of the innovation program, we determine that the profitability in the company will significantly increase by $75 \%$ and amount to $37.125 \%$. [12]

1. Compliance with the company's development strategy. Focusing on the priorities established at the zero stage, as well as the results of the first stage of the assessment, we obtain the following results [13].

Table 4. The effectiveness of innovation in the first stage

\begin{tabular}{|l|l|}
\hline \multicolumn{1}{|c|}{ Strategic priority } & \multicolumn{1}{c|}{ Way to achieve } \\
\hline $\begin{array}{l}\text { Strengthening the innovative activity of the } \\
\text { organization }\end{array}$ & $\begin{array}{l}\text { - with a decrease in costs with a simultaneous } \\
\text { increase in turnover; } \\
\text { - with a decrease in the cost of the company's } \\
\text { services due to a decrease in the cost margin. }\end{array}$ \\
\hline $\begin{array}{l}\text { Increasing the share of profit attributable to } \\
\text { results from innovation }\end{array}$ & $\begin{array}{l}\text { - while maintaining the same selling prices or } \\
\text { decreasing them 20.73 and } 25.88 \% \text {, respectively. }\end{array}$ \\
\hline Increasing the company's innovativeness & $\begin{array}{l}\text { - while maintaining the condition that the risk } \\
\text { coefficient will be more than one in both cases. }\end{array}$ \\
\hline
\end{tabular}

2. Critical factors. [14] Provided that the price remains at the same level, as well as the range of its fluctuations for products and services as a result of the introduction of innovative activities in the amount of $20.23 \%$, there is every chance of increasing its market share with a positive prospect of its strengthening, in addition, it appears a significant opportunity to prevent the transition of key customers to substitutes by minimizing transaction costs and the complete absence of any requirements of a technical, financial, etc. nature to them [15].

\section{Discussion of the results}

An experimental test of the methodology for assessing the effectiveness of innovative activities of companies in the agro-industrial complex was carried out according to the data provided by the company. The survey regarding the need to implement the system, as well as its development was conducted among the following groups of respondents of the organization: clients; leadership; direction managers responsible for the implementation and maintenance of the system [16].

Thus, it has been established that most of the directions, within the framework of the development of the company's innovative activities, are of high interest in the eyes of customers, the organization's leadership and project management. 


\section{Conclusions}

The main goals of the company's development should be the preservation of the product portfolio and the development of new areas of activity. Focusing on the competitive environment, it was determined that the expansion of sales markets is a priority condition for the development of a company in the external environment. The partner companies appreciate the program for the implementation of the innovative development complex.

Among the strategic priorities were identified:

- strengthening the innovative activity of the organization;

- increasing the share of profit attributable to the results of innovation;

- increasing the company's innovativeness, especially in the eyes of partners.

Structural factors should be:

- strong market position of the company in relation to competitors;

- strong relationships with investors;

- provision with all necessary resources.

The proposed complex for the development of innovative activities, according to consumer companies, is able to significantly simplify the pricing procedure and focus on programs to reduce selling prices to retail consumers. The direct management of the organization and the project management team places high hopes on the organization's innovative development program, because there is an opportunity to identify the most promising market niches.

\section{References}

1. A. Nazifi, S. Murdy, B. Marder, J. Gäthke, B. Shabani, A Bit(coin) of happiness a fter a fai lure: An e mpirical examination of the effect iveness of c ryptocurre ncies as an innovative recovery tool. Journal of Business Rese arch 124, 494-505 (2021) doi.org/10.1016/j.jbusres.2020.11.012

2. S. Botwright, A.-L. Kahn, R. Hutubessy, P. Lydon, How can we ev aluate the pote ntial of i nnovative $\mathrm{v}$ accine products and technolog ies in resou rce constr ained sett ings? A tot al systems e ffectiveness (T SE) approach to decis ion-making, Vaccine: X 6(11), 100078 (2020) doi.org/10.1016/j.jvacx.2020.100078

3. D. N. Lambert, A. Swartzendruber, Examining I nnovative D igital Met hods for He alth Promotion: The Feasibility a nd Cost-Effectiveness of Reaching Se xually Act ive Adolescent Substance Users in the South Through Online Social Networking Platfo rms. Journal of Ado lescent He alth 66(2), S137 (2020)

4. K. Kozioł-Nadolna, J. Wiśniewska, Supporting Managerial Dec isions with IDI in the Organization's In novative Act ivities. Procedia Computer Science 176, 2783-2793 (2020) doi.org/10.1016/j.procs.2020.09.278

5. M. Buffart, G. Croidieu, P. H.Kim, R. Bowman, Even winners need to le arn: How gove rnment ent repreneurs hip programs can support innovat ive ventures, Research Po licy 49(10), 104052 (2020) doi.org/10.1016/j.respol.2020.104052

6. E.M. Gimenez-Fernandez, F.D. Sandulli, M. Bogersbc, Unpacking liabilities of newness and smallness in innovative start-ups: Investigating the differences in innovation performance betwee n new and o lder small firms, Research Policy 49(10), 104049 (2020) doi.org/10.1016/j.respol.2020.104049

7. D. Herzer, How does mortality af fect innov ative activity in the long run? World Deve lopment 125, 104688 (2020) doi.org/10.1016/j.worlddev.2019.104688 
8. D. Kim, J. Shin, M.-G. Seo, M.-Ji. Sung, Enjoy the pain that you cannot avoid: Investigation on the relationship between developmental job experience and employees' i nnovative be havior, Journal of Bus iness Rese arch 126, 363-375 (2021) doi.org/10.1016/j. matpr.2019.05. 221

9. R. Henao, W. Sarache, I. Góme z, Lean ma nufacturing and sustain able perfo rmance: Tre nds and future challenges, Jou rnal of Cle aner Product ion 208, 99-116 (2019) doi.org/10.1016/j.jbusres.2020.12.064

10. J.M. Cramm, M.M.H. Strating, R. B al, A. P.Nieboer, A large-sc ale longitud inal study indicating the importa nce of perce ived effect iveness, o rganizatio nal and ma nagement support for innovative culture, Social Science \& Medic ine 83, 119-124 (2013) doi.org/10.1016/j.p romfg.2019.04.04 3

11. A. Kurt Möldner, J. Artu ro Garza-Reyes, V. Ku mar, Explo ring lean m anufacturing practices' influence on process i nnovation pe rformance, Jou rnal of Bus iness Rese arch 106, 233-249 (2020) doi.org/10.1016/j.socscimed.2013.01.017

12. D. Audretsch, A. Colombelli, L. Grilli, T. Minola, Einar Rasmussenf, Innovative st artups and policy initiatives, Research Policy 203, 301-310 (2020) doi.org/10.1016/j.respol.2020.104027

13. K.A. Barmuta, A.A. Borisova, M.P. Glyzina, Features of the modern system of manageme nt of deve lopment of e nterprises. Med iterranean Jou rnal of Soc ial Sciences 6(3S4), 91- 96 (2015) doi: 10.5901/ mjss.2015.v6n3s4p91

14. V.V. Mazur, K.A. Barmuta, S.S. Demin, E.A. Tikhomirov, M.A. Bykovskiy, Innovation clusters: Adv antages and disadvantag. Internat ional Jour nal of Eco nomics and $\mathrm{F}$ inancial Issues 6(1S), 270- 274 (2016)

15. K. Barmuta, V. Ponkratov, M. Maramygin, N. Kuznetsov, V. Ivlev, M. Ivleva, Mathematic al model of optimizing the bal ance sheet st ructure of the Russian b anking syste $\mathrm{m}$ with allow ance for the foreign exchange ris $\mathrm{k}$ levels. Entrepreneu rship and Sust ainability Issues 7(1), 484-4 97 (2019) doi: 10.9770/jes i.7.1(34)

16. N. S. Plaskova, N. A. Prodanova, A. S. Samusenko, E. A. Erzinkyan, K. Barmuta, R. A. Shichiyakh, Investment dec isions for mation: In novative assets. Internation al Journal of Engineering and Advanced Technology 9(1), 2913-2916 (2019) do i:10.35940/ijeat.A1213.109119 